\title{
O Alienista: loucura, poder e ciência
}

\author{
ROBERTO GOMES
}

RESUMO: Este artigo analisa o conto de Machado de Assis, O Alienista. Ficção centrada nos delírios de Simão Bacamarte, médico-psiquiatra, nela estão referidas as pretensões e impasses das concepções científicas do século XIX, em particular do Positivismo, que tem vínculos profundos com o nascimento das Ciências Humanas. De um lado, a sede de explicação rigorosa de seu objeto, no caso, a Loucura, e, de outro, o direito que se arroga de dizer a verdade a respeito da Loucura e do Louco e de agir sobre ele com plenos e legítimos direitos. A obra de Machado denuncia o vínculo entre ciência e poder bem como a usurpação, pelo homem de ciência, do direito que cada um tem de dizer a sua própria verdade. O que conduz à ironia final: parece haver mais loucura na pretensão de estabelecer com nitidez a linha divisória entre Razão e Loucura do que em perder-se entre seus supostos limites.

\section{A imagem vivaz do gênio}

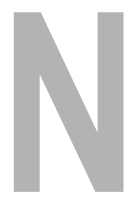

ão percamos a imagem preciosa:

"Crispim Soares, ao tornar à casa, trazia os olhos entre as duas orelhas da besta em que vinha montado; Simão Bacamarte alongava os seus pelo horizonte adiante, deixando ao cavalo a responsabilidade do regresso. Imagem vivaz do gênio e do vulgo! Um fita o presente, com todas as suas lágrimas e saudades, outro devassa o futuro com todas as suas auroras" (Assis, 1979, p. 259).

Imagem vivaz do Alienista. Simão Bacamarte surge como um moderno cavaleiro andante da ciência. Desbravador, sua vida é feita de rupturas e separações que fariam o vulgo sofrer - mas dela as lágrimas e saudades
UNITERMOS:

ciência,

loucura,

poder,

O Alienista,

Machado de Assis, positivismo.

Este texto se origina de uma palestra proferida no dia $27 / 04 /$ 83, durante o Ciclo de Palestras Loucura e Verdade, organizado pela Clínica Quarta Vila, em Curitiba, PR.

Escritor e Professor de Filosofia da Universidade Federal do Paraná. 
foram banidas. Nada o comove exceto a ciência. Goza apenas das alegrias reservadas a um sábio e sobrevive num mundo dividido. O presente e o futuro. A besta e o gênio. O sábio e o vulgo. A razão e o sentimento.

Afastou-se da corte e das missões que lhe oferece el-rei e descobre que a ciência é seu único emprego e, Itaguaí, seu universo. Não terá filhos - a infertilidade, é óbvio, será de imediato atribuída à sua mulher -, o que não o abala. A ciência é seu lenitivo e entrega-se à tarefa de estudar a patologia mental, a ocupação mais digna de um médico.

Estudará a loucura, classificará seus tipos - e é certo que descobrirá suas causas e o remédio universal. Funda seu continente: a loucura. A recorrência insistente a metáforas geográficas (universo, continente, limites, ilha, oceano) delimita seu campo de luta e sua obsessão: em que lugar poderá desvendar o último segredo da perturbação da mente humana?

"A loucura - ele descobre, ao despedir-se de D. Evarista, que viaja ao Rio - objeto de meus estudos, era até agora uma ilha perdida no oceano da razão; começo a suspeitar que é um continente” (p. 260)․․

Os horizontes do Alienista se ampliam. O espírito humano é uma concha e, nela, habita uma pérola, a razão. Cumpre abrir a concha, submetê-la ao rigor da ciência, extrair a pérola. Neste continente a ser conquistado é preciso evitar toda imprecisão, toda delicadeza de distinções: só há um caminho possível, a delimitação exata, científica, dos limites que separam razão e loucura. E a concha se abre (ou não, pois a ciência é uma investigação constante): a saúde mental deve ser entendida como o "perfeito equilíbrio de todas as faculdades. Fora daí, insânia, insânia e só insânia” (p. 261).

Cavaleiro andante e desbravador, tomado de "volúpia científica", Simão Bacamarte segue de olhos postos no horizonte: "A ciência é a ciência", afirma, assumindo seus direitos de homem raro, colocado acima do bem e do mal - não dará explicações de seus atos a seres vulgares. A Casa Verde é um templo e ele o sacerdote: só Deus e os mestres sabem melhor. As críticas a seus atos procedem do vulgo, do presente e do imediato - seu discurso desqualifica os que querem ver nele um delirante, um homem que, por ter estudado demais, perdeu o juízo. De resto, tais críticas só evidenciam o desequilíbrio mental de seus opositores. A ciência, que vive em seu espírito e em cada detalhe de seu corpo, assegura suas imunidades.

Homem de ciência, não hesitará em trancafiar a própria mulher na Casa Verde. O que lhe sugere uma nova teoria: considerando que havia falhas em suas concepções anteriores, decreta o inverso do que pregara até então - o que não abala sua fé na ciência, antes a reforça, pois ela é investigação cons-

'Para evitar repetições, as citações são acompanhadas pelo número de página da edição de O Alienista que utilizei e que consta das referências bibliográficas. tante. A razão, conclui, é o desequilíbrio. Mudada a norma, 4/5 da população de Itaguaí deixa de ser formada por loucos e são liberados da Casa Verde. Resta agora procurar no quinto restante os verdadeiros insanos: os equilibrados. Tarefa na qual avança destemido, como sempre, "virgulando as falas de um olhar que metia medo aos mais heróicos" (p. 260). 
A ciência não fracassa jamais. A nova teoria também se revela falsa, mas uma novíssima teoria se avizinha. A rigor só há um louco em Itaguaí, posto que só um dentre os habitantes deste continente pode ser tido como perfeitamente equilibrado, sem defeitos ou vícios: ele próprio. E Bacamarte mergulha mais além em busca da última verdade.

"Nem rogos nem sugestões nem lágrimas o detiveram um só instante. (...) - A questão é científica, dizia ele; trata-se de uma doutrina nova, cujo primeiro exemplo sou eu. Reúno em mim mesmo a teoria e a prática” (p. 288).

Tratando-se de questão científica, não dá ouvidos a sentimentos miúdos, coisas do vulgo - "com os olhos acesos da convicção científica, trancou os ouvidos à saudade da mulher" - e trancafiou-se na Casa Verde, inteiramente voltado para o estudo e a cura de si mesmo.

História comovente: cego a seus próprios destroços, o caminhante segue em frente. $\mathrm{O}$ cavaleiro andante preserva sua imagem: olhos postos no futuro onde, celebrante e seguidor da ciência, pensa conquistar o paraíso da razão.

Dezessete meses depois, segundo cronistas da época, ali seria encontrado morto,

"No mesmo estado em que entrou, sem ter podido alcançar nada” (p. 288).

\section{Um século}

Originalmente publicado entre 1881 e 1882, O Alienista faz parte da coletânea Papéis Avulsos, editada em 1882.

As datas desta obra já centenária nos colocam nos limites de um século que se assumiu cientificista e nos arredores de modificações substanciais na vida brasileira: estão no ar os ideais republicanos e o positivismo é um caldo no qual todos parecem imersos. Nem todos, é claro. Machado não está entre eles: o olhar cético não o abandona.

Um século seria tempo suficiente para corroer uma obra. Mas não é o caso. Em $O$ Alienista talvez seja legítimo descobrir um tratamento inédito e quase profético da questão da loucura, já que as ligações entre poder, ciência e loucura só virão a ser debatidas explicitamente na década de 1960. Privilegiando a análise da loucura como momento de eclosão do pensamento de uma época, Machado realiza dela um desvelamento que incide sobre um ângulo decisivo da questão: sua face política. Ou seja: interessa a Machado o jogo de forças que se defrontam em torno da normatização (toda a tragédia de Bacamarte oscila entre os diversos critérios de normalidade que busca colocar em prática) posta em andamento pela ciência, que se imaginava tão nobre e imparcial. Assim, a fala da medicina psiquiátrica é tratada como exercício de poder: o que autoriza Bacamarte a agir "virgulando as falas de um olhar que metia medo aos mais heróicos" (p. 260). 
O Alienista não se debate apenas nos confrontos internos do discurso da loucura (a busca dos critérios, a exigência de rigor, as classificações, o bloqueio das emoções, o messianismo civilizatório da ciência). Sua vigilância científica desencadeia um poder que altera a vida da comunidade de Itaguaí. Neste sentido, Machado realiza obra contemporânea: uma investigação de natureza política em torno do poder da ciência.

\section{Literatura e verdade}

Mas $O$ Alienista é, antes de mais nada, uma obra de ficção - e como tal deve ser tratada. Não é um ensaio, não defende teses. Seu relacionamento com a verdade, por mais incisivo, é de outra ordem. Se há uma verdade para a literatura, esta não reside na organização lógica dos juízos, em sua organização formal ou referência material à realidade. Para a literatura a verdade é uma questão vital na medida em que gera narrativas: seus episódios, peripécias, fazendo-se carne e ossos dos personagens. Não há em literatura demonstração discursiva possível, a não ser quando se amesquinha em ser mera transcrição linear do real, tido por imediatamente evidente. Não é o caso, porém. Obras deste tipo não sobrevivem a um século.

A ciência, ao contrário, vive de momentos, palavras, regras e instrumentos que imagina propícios à verdade - seus rituais de produção: o laboratório, os conceitos, as definições, as demonstrações. E vive também dos lugares de privilégio onde são buscadas as verdades: o hospital, o hospício, a academia, a escola, etc.

Já um escritor trabalha a partir de coisas mínimas. Às vezes um gesto, uma frase, pequena situação, uma palavra. Um robe de chambre, por exemplo. Ou um par de sapatos. Trata-se de descobrir quem disse tal frase, fez tal gesto, encontrou-se em tal situação. E imaginar então em que circunstâncias este conjunto de forças pode ser levado a seu limite. A arte da ficção cria um texto cuja alta concentração de energias permite a eclosão de uma verdade.

Em outras palavras: o que chamamos de real - cujo sentido só acontece diante de nosso olhar - é, ao final das contas, aquilo sobre o que admitimos nada saber. Seria este conjunto informe, caótico, suposto por detrás do que vemos. Diante dele, a literatura - e isso tem em comum com a ciência - irá criar um mundo unitário, organizado, necessário. Ainda que seja para demonstrar o caos. Acatando a advertência de Tchecov poderíamos dizer que, se há um punhal em cena, ele será usado. Não necessariamente para matar. Usado ficcionalmente, ou seja: para significar.

Assim, a literatura lida com situações-limite, ou situações-síntese - núcleos narrativos capazes de detonar a eclosão da verdade. Seja a verdade de uma paixão adolescente, em Uns Braços, a verdade da morte, em Memórias Póstumas de Brás Cubas, ou a verdade da loucura, em $O$ Alienista. 


\section{A loucura e a verdade}

Cabe perguntar: que verdade interessa a Machado de Assis em $O$ Alienista? Ou, dizendo de uma maneira mais rigorosa: que verdade - eliminada a referência ao Autor - está em questão no texto $O$ Alienista?

A resposta parece ser simples: trata-se da verdade a respeito da loucura, sendo a loucura uma das situações-limite que - no Quixote, por exemplo, - têm sido exploradas com muita freqüência em termos ficcionais. $\mathrm{Na}$ literatura se preserva a convicção de que uma das maneiras privilegiadas de se produzir a verdade seja enlouquecendo o personagem, o que remonta a uma época em que ao louco se concedia o direito à fala. Idéia generosa, é claro, que retoma a velha tradição literária daquilo que Michel Foucault chamou de "percepção trágica da loucura" - a qual o século XVII se ocupou em soterrar e que respeita o vínculo entre loucura e verdade. Se os espaços para a verdade estão bloqueados, resta um recurso: enlouquecer. Com isso deixaríamos de estar aprisionados às limitações que a saúde mental impõe ao comum dos mortais, possibilitando um discurso capaz de romper com as conveniências da normalidade: a hipocrisia e o medo. Desta forma, é preciso que o Quixote enlouqueça - e é preciso que Simão Bacamarte caia sob a mesma situaçãolimite.

Mas permanece uma questão: do que se fala, em O Alienista, quando se fala da loucura? E a quem pertence esta loucura?

Não é de loucura que se fala, certamente. Machado não lança sobre a loucura nenhum olhar de inspeção ou análise. Também não fala da loucura como conceito ou comportamento, nem como entidade ou estado. Não há nesta novela qualquer preocupação com algo que pudesse ser definido como loucura, por mais que isso seja uma preocupação constante em Bacamarte. A rigor, ainda que ele enlouqueça - e ainda que a partir de dado momento haja uma "torrente de loucos" em Itaguaí - a questão da loucura não se coloca. Ou seja: não se coloca tal como surge aos olhos do Alienista. Temos dois recortes possíveis: em primeiro lugar, a obsessão permanente do psiquiatra em aprisionar o germe da loucura. Diz ele:

"O principal, nesta minha obra da Casa Verde, é estudar profundamente a loucura, os seus diversos graus, classificar-lhe os casos, descobrir enfim a causa dos fenômenos e o remédio universal" (p. 256).

Armado do instrumental da ciência de seu tempo - em poucas palavras está retratada a nosografia da época -, Simão Bacamarte mergulha numa viagem sem retorno em busca da norma que possa estabelecer com rigor os limites entre a razão e a loucura. Esta a verdade do Alienista, sua paixão.

Segundo recorte: não é esta a verdade buscada pelo texto ficcional de Machado de Assis - menos ainda a verdade que irá eclodir ao seu final. Por mais que o Alienista seja capaz de produzir verdades a respeito da loucura, o texto não está interessado em contestá-las, discutí-las, colocando-as abaixo 
ou acima de quaisquer outras que possam servir de parâmetro para analisálas. Ou seja, no lugar do projeto enlouquecido de Simão Bacamarte, Machado não deseja colocar coisa alguma - talvez porque isso seria fazer o mesmo que o Alienista. Machado quer, isso sim, puxar o tapete sobre o qual repousa todo este delírio, revelando seu fundamento: o próprio empreendimento normatizador. Limita-se, portanto, a narrar as proporções de um grande desastre. Não se trata de decidir entre esta ou aquela concepção da loucura. Trata-se de corroer as bases do projeto psiquiátrico.

\section{A parábola do texto}

Assim, não se fala da loucura ou dos loucos, por mais que o Alienista tente fazê-los atuar. De resto, os loucos e sua loucura são uma presença apaziguadora e até cômica ao longo do texto. Fala-se, isso sim, deste homem e de seu discurso que é capaz de produzir a loucura.

Pois é esta a parábola descrita pelo texto: no início da narrativa, não há loucos em Itaguaí, cidade que tinha o "ruim costume", segundo o Alienista, "de não fazer caso dos dementes". Estes, quando mansos, andavam à solta, e, quando furiosos, ficavam trancafiados em casa. De resto, eram poucos e não criavam maiores problemas. Quer dizer: não havia loucos em Itaguaí, não havendo quem levantasse a questão científica da loucura.

É este mau costume que o Alienista deseja consertar, introduzindo a esquecida cidadezinha no século da ciência e da razão. Tão logo inicia sua empreitada, eis o que ocorre: uma verdadeira "torrente de loucos". Eles surgem de toda parte - monomaníacos, loucos por amor, vítimas de mania de grandeza. E, diante da perplexidade geral, simbolizada pelo espanto ingênuo de Pe. Lopes, a quantidade de loucos só faz aumentar na medida em que o Alienista segue em seus estudos e amplia o poder de seus conceitos. No auge, 4/5 da população da cidade está trancafiada dentro dos muros da Casa Verde.

Mas isso não é tudo. Seguindo o curso da parábola, e em função das novas descobertas que faz, Simão Bacamarte desiste de buscar o germe da loucura nos outros, voltando-se para si mesmo como objeto de investigação. "Reúno em mim mesmo a teoria e a prática", conclui ele, descobrindo-se sujeito e objeto da ciência nascente. Desta forma, cessando a atividade produtiva da loucura por parte do Alienista, já não há loucos em Itaguaí. Ou há um só.

Parábola em três tempos. Um: antes da intervenção do psiquiatra não existem loucos. Dois: sua ação desencadeia uma torrente de loucos. Três: saindo de cena o cientista, haverá no máximo um louco, ele próprio, que decide assim se constituir.

Não está em questão, portanto, a natureza da loucura ou de alguma teoria científica. O texto é claro: não há em Itaguaí loucura alguma, exceto a daquele que a produz. 


\section{A produção da loucura}

Simão Bacamarte exercita a produção da loucura - e é isso que está em cena. Gera os loucos antes inexistentes, decreta normas que incluem ou excluem certos indivíduos do continente da loucura. Ao final se imagina o único capaz de sofrer e conhecer a loucura. Teoria e prática. Experiência e vida. Deixa de ser um simples gerador para transformar-se na encarnação da loucura: sua paixão, sua ação. Seu universo e seu emprego único. Sujeito e Objeto.

Trata-se de um ardil, é claro. A ciência é investigação constante, ele repete. Este homem não cede à loucura senão para melhor submetê-la ao domínio possível da ciência. Ardil enlouquecido, no entanto: atrai para si o malefício que irá afrontar. Quando todas as experiências falharam, quando todas as teorias foram refutadas, lança o último golpe - "plus ultra!" exclama - e se converte em sujeito e objeto, trancafiando-se em definitivo na Casa Verde. Só assim o ideal científico de unificação entre sujeito e objeto poderá se realizar: Simão Bacamarte é a ciência e aquilo sobre o que a ciência falará. Realização vivaz e irônica da imagem positivista: estar à janela e ver-se passando na rua. Seu domínio, para nos referirmos a Foucault, subentende a "reduplicação transcendental". A loucura da ciência se revela por inteiro.

Estamos em pleno domínio do Alienista, seu continente ilhado. Mas, além do delírio cientificista, encontramos no texto outro recorte mais radical a respeito do sonho de constante investigação científica: finalmente isolado após trancafiar 4/5 da população dentro da Casa Verde - ele termina por trancafiar o mundo fora da Casa Verde. E mergulha na última viagem, da qual não haverá retorno:

"Fechada a porta da Casa Verde, entregou-se ao estudo e à cura de si mesmo. Dizem os cronistas que ele morreu dali a dezessete meses, no mesmo estado em que entrou, sem ter podido alcançar nada" (p. 288).

O delírio racionalista da investigação constante conduz ao isolamento. A sede de uma explicação definitiva e universal conduz à morte. Simão Bacamarte morre "no mesmo estado em que entrou" e sem "alcançar nada". Em termos de parábola, absolutamente perfeito. Literariamente exato, redondo, definitivo. Nada sobra neste final - e nada mais precisa ser dito.

\section{A loucura do século}

É claro que podemos investigar os caminhos que levaram a este final desastroso. Por exemplo: o que movia este produtor de loucura? Que impulso o lançava adiante? O que o tornava apto a produzir a "torrente de loucos"? No que se escudava para estar acima do bem e do mal, longe das mesquinharias miúdas em que o vulgo se perdia à sua volta? E mais: o que lhe concede privilégios e imunidades tais que o autorizam a trancafiar $4 / 5$ da cidade e, ao final, trancafiar ao mundo inteiro fora da Casa Verde, mergulhan- 
do no nada e mantendo de si a mesma "imagem vivaz" e triunfante do cientista que irá desvendar - plus ultra! - o último segredo da mente humana?

A loucura do Alienista não é a loucura de Simão Bacamarte. Ele, que tem de si uma imagem de ser único e predestinado - acima do vulgo - não é na verdade este ser exclusivo que, na frente de batalha, luta como indivíduo raro em prol da felicidade dos povos. Simão Bacamarte enlouquece, é verdade. Em sua loucura está contido, desde o início, o final trágico. Mas não enlouquece sozinho e nem enlouquece a si mesmo. É enlouquecido. Ele, que tem uma visão deformada da própria liberdade de criar um mundo novo, está desde o início vivendo uma tragédia coletiva, esta sim, a raiz da loucura que interessa a Machado: a grande loucura cientificista e positivista, que implica na busca dos limites entre razão e desrazão. A loucura de se pretender alcançar uma explicação exaustiva e racional para a "mente humana". Aí está a origem e o fundamento das imunidades e privilégios que o Alienista a si concede. São as imunidades e privilégios que o século concede à ciência, particularmente à ciência médica em sua busca de administração da vida. O Alienista, portanto, não se escolhe louco. O século o constitui assim.

Aquilo de que se fala, portanto, é deste saber que, pretendendo esgotar - de forma objetiva e rigorosa - o conhecimento a respeito da mente humana, apóia-se numa pretensão de conhecimento total do mundo e, portanto, se destina ao fracasso. Fracasso que não será devido apenas à exagerada pretensão. Antes a um esquecimento que a ciência, de má fé, realiza: seu grande triunfo é apresentar-se como forma objetiva e racional (portanto, incontestável, exceto dentro do próprio sistema que institui) de conhecimento - ou seja: como algo fora das fraquezas humanas, fora do vulgo, das coisas miúdas. Eis porque esta metáfora do que está dentro e fora é essencial e sempre se repete: a ciência inclui e exclui num só ato: valida e desqualifica num mesmo momento - quer dizer: ou se está fora ou dentro da Casa Verde, no interior ou no exterior do continente; eis porque é necessário se colocar fora do mundo para que se possa estar dentro da Casa Verde (síntese institucional das pretensões científicas) e, aí, realizar a grande investigação final.

A ciência decreta assim sua própria insanidade - que levará à morte, ao isolamento, ao nada - no momento em que se pretende acima do bem e do mal, reivindicando para si uma isenção de tudo aquilo que não for a simples razão (já suposto o racional como o verdadeiro), ou seja, como se seu poder derivasse de uma lógica metafísica embutida no real e na razão - vistos como pares complementares -, lógica da qual seria insânia tentarmos escapar.

Ao fazer isso, a ciência apresenta-se como desinteressada - o que equivale a dizer: como não representando interesses fora daqueles que são próprios à busca da pura verdade. Nisso reside sua insensatez.

\section{0 poder da ciência}

Desta forma, em $O$ Alienista se fala da ciência, mas de uma forma inédita até então: não se fala da ciência enquanto tal, seus métodos, sua vali- 
dade, sua pretensão de conhecimento, seu rigor lógico, suas tendências, sua extensão. Não há aí nenhuma epistemologia no sentido clássico, muito menos alguma filosofia da ciência. Não se fala, pois, da ciência - o que seria usual e fastidioso para a época; fala-se do poder da ciência - o que representa uma raridade para aquele momento. Machado está preocupado em colocar diante de nossos olhos a pergunta fundamental do ponto de vista da política do saber: que poder é este que emana da ciência, no que se funda, qual a razão das imunidades e privilégios que o Alienista toma para si? Em suma: nenhum poder é inocente; todo poder deve ter contestadas suas razões.

Eis porque Machado não está preocupado com outro modo de conceber a loucura - que seria mais "verdadeiro" - nem se preocupa com outro tratamento aos asilados - que seria mais "humano". Por isso o texto não contém denúncias ou reivindicações. Não há preocupação com outro caminho para a ciência patológica e não se coloca em questão a competência de Simão Bacamarte enquanto cientista: ele é, ao contrário, o mais rigoroso e consequiente dos cientistas, coerência que lhe cobrará a razão e a vida.

A tensão fundamental do texto está noutro lugar: o poder da ciência que a retórica científica pretende mascarar. Machado está além de seu século não apenas por questionar a concepção racionalista e positivista de ciência, mas por questionar o poder de todo e qualquer saber que pretenda apresentarse como rigorosamente objetivo e com pretensões universais. Não há, portanto, razões para sermos otimistas quanto à razão e à ciência.

No entanto, mesmo no momento de crítica radical, Machado não se coloca na mesma linha de tiro de seus alvos. Ele não desespera da ciência enquanto conhecimento, resultado, investigação. Nem a razão lhe parece um mal. O que Machado mira, por detrás da hipocrisia humanitária do positivismo, da sede de esgotar as razões do universo e da vida humana, é a insânia do exercício de poder inerente à concepção de conhecimento (e ao tipo de fundamentação do conhecimento), que a razão e a ciência positivistas enaltecem. $\mathrm{O}$ alvo em mira é o poder, essa coisa escorregadia, que não diz seu nome, que gera as mil máscaras por atrás das quais se esconde.

\section{A disciplina do corpo}

Simão Bacamarte descreve uma trajetória de desastre - rodeado pela mediocridade, intriga, inveja, hipocrisia - mas, em meio a tudo isso, não deixa um só momento de fazer de seu corpo a "imagem vivaz do gênio". Simão Bacamarte é o corpo disciplinado.

A idéia da ciência é, de fato, sua única ocupação. Mas ela não está apenas em sua cabeça ou em sua biblioteca. Ela percorre todo seu corpo, suas vestes, suas falas, seus gestos: transformou seu corpo na expressão acabada de seu ideal e nada nele escapa a esta determinação obsessiva. De todos os continentes, é o corpo que deve ser conquistado em primeiro lugar, pois ele é o objetivo, o lugar e o instrumento de luta. Desde o início não é Simão Bacamarte quem vive - é a ciência que molda seu corpo com sua disciplina. 
Ao lado das metáforas geográficas - que comprovam que Simão Bacamarte está numa guerra e se porta como audaz estrategista - as referências à ciência são as mais freqüentes ao longo do texto.

Desprezando os negócios da Corte, o Alienista elege seu universo, Itaguaí, e seu "emprego único": "entregou-se de corpo e alma ao estudo da ciência" (p. 253). Seu projeto está lançado. Tanto o corpo quanto a alma estão desde o início envolvidos neste negócio. A ciência cobra de seus amantes não apenas a mente, mas também o corpo, que será moldado aos poucos e decididamente, em busca da "imagem vivaz do gênio".

Não se trata de uma escolha acadêmica - neste caso teria preferido os benefícios da Corte - já que não se importa com vantagens monetárias ou honrarias que sobrem na periferia do poder monárquico. É uma escolha de vida, a opção por um poder que não será periférico nem ocasional, mas de um poder mais alto, que a seus olhos se apresenta como a possibilidade de colocar Itaguaí e o universo "à beira de uma revolução". Um poder, no entanto, que vai lhe cobrar o controle e o domínio pleno de seu corpo.

Assim, não será segundo diretrizes miúdas e vulgares que selecionará sua esposa. A escolha de D. Evarista será feita segundo os princípios de uma demonstração racional. Trata-se de uma mulher despida de atrativos, "mal composta de feições".... "não bonita, nem simpática" (p. 253-254). Mas que importância tem isso para um sábio? Importam, isso sim, as condições fisiológicas e anatômicas da esposa, o fato de dormir regularmente e digerir com facilidade. De resto, sendo feia a esposa, teria um motivo a menos para se afastar das nobres ocupações dignas de um sábio.

"Não corria o risco de preterir os interesses da ciência na contemplação exclusiva, miúda e vulgar da consorte" (p. 254).

A alma e o corpo do Alienista - do qual, aliás, D. Evarista não passa de um apêndice necessário apenas à reprodução biológica - parecem estar em harmonia. Mas surge um pequeno problema: D. Evarista, apesar dos remédios e das carnes de porco que lhe receita o marido, é incapaz de gerar filhos - a isso "devemos a total extinção dos Bacamartes" (p. 254). O sábio não se abala, porém. A ciência, reflete, tem o "dom de curar todas as mágoas" (p. 254) e o Alienista mergulha mais e mais nos estudos, sua verdadeira missão, descobrindo neste momento o setor da medicina que deve merecer seus esforços: "A saúde da alma, bradou ele, é a ocupação mais digna do médico" (p. 254).

Há dois recortes, novamente: o do Alienista e o do texto de Machado. O Alienista vê nesta miúda desgraça um sinal a mais a projetá-lo na direção das investigações científicas, agora que localizou onde exercê-las. Machado assinala, como o fará ao longo de todo o texto, a atabalhoada atitude do Alienista, sempre negando os desastres de sua vida em troca dos delírios de um sábio. Há um homem que sofre e se frustra por ver extinta a "dinastia dos Bacamartes", e há um homem que entrega seu corpo e sua alma à ciência.

Daí decorrem duas vertentes na narrativa: de um lado, o elogio so- 
lene da ciência e da razão; de outro, o progressivo desastre afetivo-corporal em que se converte o Alienista.

Sufocadas, suas paixões, medos, ansiedades e dúvidas, vão ressecando seu caráter, esmagando qualquer manifestação de fraqueza ou afeto. Quando D. Evarista despede-se para viajar ao Rio, o Alienista vai ao botafora na maior indiferença, pois, "homem de ciência, e só de ciência, nada o consternava fora da ciência" (p. 259). Um homem só de ciência, além de não se comover, não perde a ocasião para vasculhar a multidão, com um "olhar inquieto e policial", verificando se por acaso algum demente não poderia terse misturado com a gente de juízo.

Seu corpo idealizado sofre apenas as paixões próprias de um sábio. Diante de um relato que lhe parece rico em sugestões psiquiátricas, é tomado de "uma volúpia científica". Quando do regresso do D. Evarista - que, vulgar, desmaia em seus braços - Bacamarte permanece indiferente, "frio como um diagnóstico, sem desengonçar por um instante a rigidez científica" (p. 286).

Assim, vai conquistando corpo a "imagem vivaz do gênio". Nos delírios de Bacamarte, temos um investigador permanente, um sábio alheio às coisas menores da vida, o olhar preso no horizonte a vasculhar o futuro, pensando teorias, dedicando-se a seu emprego único. No tecido do texto de Machado, porém, vai surgindo um corpo dilacerado, que se compraz em ser frio como um diagnóstico e cientificamente rígido.

Já próximo do final - de sua "última verdade" - meditará solitário, passeando pela vasta sala onde tem sua biblioteca e compondo esta triste figura:

\section{"Um amplo chambre de damasco, preso à cintura por um cordão de seda, com bordas de ouro (presente de uma universidade) envolvia o corpo majestoso e aus- tero do ilustre alienista. A cabeleira cobria-lhe uma extensa e nobre calva adquirida nas cogitações quoti- dianas da ciência. Os pés, não delgados e femininos, não graúdos e mariolas, mas proporcionados ao vulto, eram resguardados por um par de sapatos cujas five- las não passavam de simples e modesto latão. Vêde a diferença: - só se lhe notava luxo no que era de origem científica; o que propriamente vinha dele trazia a cor da moderação e da singeleza, virtudes tão ajustadas à pessoa de um sábio" (p. 286).}

É o corpo falante, submisso ao discurso científico. A ciência é disciplina, sabe Machado. Poder e disciplina. Enquanto conjunto de ensinamentos e enquanto normatização que se cristaliza num corpo. Assim, embora de início pudesse parecer o contrário, não há no Alienista um separação entre um ideal científico exaltado e um corpo relegado às coisas irrelevantes. Seu corpo e sua mente, seus ideais e seus afetos, são uma coisa só: "reúno - poderá ele dizer então - em mim mesmo a teoria e a prática". Esta é uma questão cientí- 
fica e, tomado por ela, mergulhará em nova investigação, rumo à "última verdade", em busca "de uma doutrina nova, cujo primeiro exemplo sou eu" (p. 288).

Mas que última verdade? Neste momento final da narrativa, Machado dissolve a dualidade com a qual vinha trabalhando, tomando o cuidado de preservar, no entanto, a distância irônica: não há uma última verdade para o Alienista, posto que nada encontrou, exceto a morte. Mas haverá uma última verdade do texto - afinal, o Alienista vivia de refutar-se continuamente. Quem sabe não terá provado alguma coisa?

\section{0 corpo da disciplina}

A loucura do Alienista não é uma tragédia somente pessoal. Ele assumiu em seu corpo, coerentemente, todos os projetos científicos da época - e isso o levou ao desastre. Mas uma coisa é certa: eram projetos científicos. Enlouquecidos, talvez, mas colados ao discurso positivista.

Tratava-se de "estudar profundamente a loucura, os seus diversos graus, classificar-lhe os casos, descobrir, enfim, a causa do fenômeno e o remédio universal" (p. 256). Projeto partilhado por inúmeros colegas de Bacamarte, tanto de ontem quanto de hoje. Projeto elevado, acima de interesses pessoais ou busca de honrarias: "trata-se de coisa mais alta, trata-se de uma experiência científica” (p. 260). Experiência assumida com todos os cuidados e escrúpulos exigidos pela ciência:

"Digo experiência, porque não me atrevo a assegurar desde já a minha idéia; nem a ciência é outra coisa, Sr. Soares - (diz ele ao boticário Crispim) - senão uma investigação constante. Trata-se, pois, de uma experiência, mas uma experiência que vai mudar a face da terra. A loucura, objeto de meus estudos, era até agora uma ilha perdida no oceano da razão; começo a suspeitar que é um continente" (p. 260).

A ciência, adverte o texto, não está livre de pretensões enlouquecidas, que não são exclusivas de Simão Bacamarte, aliás. Não se trata apenas de investigar (um investigar sem pretensão e metafísico), mas de conquistar. A ilha perseguida se revela um continente - o universo acanhado de Itaguaí se amplia, universaliza-se ao toque mágico da abstração científica. E, metáfora geográfica, diante deste continente o Alienista se coloca como um cavaleiro andante.

Mesmo que se queira evitar, em vários momentos nos invade a mente a imagem do Quixote. E nem lhe falta um Sancho Pança na figura servil, medrosa e chã de Crispim Soares, que seria a imagem vivaz do vulgo. Em seus combates, Bacamarte cruza lanças não contra moinhos de vento ou cavaleiros andantes, mas contra teorias e idéias vulgares - as quais, submetidas a seu espírito privilegiado, acabam se revelando igualmente fantasmagóricas. Desastrado e delirante como Quixote, sua empreitada também terminará em 
morte. Mal erguia seu próprio mito, a ciência já encontrava um quixote-alienista para lhe apontar seu fim (enquanto meta e enquanto morte) - mas, no caso, os quixotes eram multidão triunfante, não só na ciência, mas também na política e nas artes. Enquanto o século delirava, Machado limitava-se a compor seu texto.

E, nele, o projeto do Alienista ganha corpo:

"Supondo o espírito humano uma vasta concha, o meu fim, Sr. Soares, é ver se posso extrair a pérola, que é a razão; por outros termos, demarquemos definitivamente os limites da razão e da loucura. A razão é o perfeito equilíbrio de todas as faculdades; fora daí, insânia e só insânia” (p. 261).

Pe. Lopes, a quem o Alienista confia a nova teoria, vê nela um absurdo, ou, pelo menos, uma tarefa colossal. Mas nada pode resistir ao triunfo da ciência. Para o esperto e assustado padre, a tarefa do Alienista tem dupla face: é absurda, pois assim a vê do ângulo da teologia cristã, certamente alarmado com o pecado que é a pretensão de se desvendar a última razão dos mistérios da mente humana: soberba e sacrilégio, desejo satânico de ser Deus. Mas, manhoso, o bom padre dependura na sua frase um adendo estratégico: tarefa colossal. Certamente lhe era difícil duvidar da ciência neste século de tantos prodígios. Não absurdo, portanto - apenas colossal. Tarefa grande demais para um homem. O cuidado se explica: quem sabe do que será capaz a ciência? A religião declinante rende sua tímida homenagem à ciência. E o que esta faz? Diz o texto: "A ciência contentou-se em estender a mão à teologia, com tal segurança, que a teologia não soube enfim se devia crer em si ou na outra" (p. 262). Entre teologia e ciência, o abismo estava cavado e o cumprimento condescendente e superior do Alienista unia e separava duas eras. "Itaguaí e o universo ficavam à beira de uma revolução" (p. 262).

\section{1. "A ciência é coisa séria"}

O poder da ciência se instala definitivamente. "Tudo era loucura" (p. 279). Poder sobre o século, poder frente à teologia, poder junto à câmara de vereadores de Itaguaí - poder sobre o continente conquistado. Não só poder de desenvolver um discurso explicativo a respeito da mente humana, mas algo mais radical: poder de estabelecer os limites entre razão e loucura e, feito isso, trancafiar aqueles que, por um "ruim costume", eram deixados à solta.

E mais: poder de colocar-se além do vulgo, que é medíocre, e dos interesses dos mortais comuns, que distorcem a verdade. O Alienista é insuspeito: seus atos jamais denunciarão impureza, mesquinharias, vinganças, escolhas políticas; serão sempre os atos de um sábio. "O marido era um sábio (raciocina D. Evarista quando da 'torrente de loucos') - não recolheria ninguém à Casa Verde sem prova evidente de loucura" (p. 266). Nem mesmo o poder da Câmara prevalecerá sobre o Alienista, pois "a ciência não podia ser emendada por votação administrativa". Sequer o povo - ainda que seja em 
nome dos benefícios à humanidade que Bacamarte lute - poderá se pronunciar. Movimentos de rua não podem contestar a ciência, é o que prova a traída Revolta dos Canjicas.

Ou seja: "A ciência é a ciência", repete o Alienista diante de dúvidas, ataques, desconfianças, imaginando se seu opositor não será mais um caso a trancafiar. A ciência não deve explicações a ninguém, tem suas próprias normas de auto-avaliação, o que compete apenas a ela própria discutir. Acima do bem e do mal, imune às suspeitas, o sábio (encarnação da ciência) não tem por onde ser contestado. Diante da Revolta dos Canjicas, o Alienista discursa à multidão:

“- Meus senhores, a ciência é coisa séria, e merece ser tratada com seriedade. Não dou razão dos meus atos de alienista a ninguém, salvo aos mestres e a Deus. Se quereis emendar a administração da Casa Verde, estou pronto a ouvir-vos; mas, se exigis que me negue a mim mesmo, não ganhareis nada. Poderia convidar alguns de vós em comissão dos outros a vir ver comigo os loucos reclusos; mas não o faço, porque seria darvos razão do meu sistema, o que não farei a leigos nem a rebeldes" (p. 272).

É difícil encontrarmos discurso mais perfeito sobre as imunidades e privilégios que a ciência a si mesmo concede, ancorada nas instituições que falam em seu nome. O único tribunal do cientista são mestres (igualmente cientistas, é claro) e Deus (que não costuma interferir em polêmicas deste tipo). Dar razão de seu sistema seria negar-se; e isso é fácil entender: o poder decorrente do saber científico não é um anexo que lhe seja acrescentado em certas condições; tal poder está no interior mesmo da concepção e do projeto científico. Quer dizer: Simão Bacamarte não delira por ter saído dos limites da ciência, mas por ter entrado neles. Não quebra nenhuma norma científica; desastrado e cego, quer cumprí-las todas com rigorosa coerência.

Disso encontramos a melhor ilustração na Revolta dos Canjicas, comandada pelo barbeiro Porfírio, e, como se não bastante, no levante seguinte, liderado por João Pina, outro barbeiro. Nos dois casos, com o detalhe de que o segundo golpista faz a cópia fiel da declaração do primeiro, resulta a confirmação de um poder que permanece inabalável: o poder de Simão Bacamarte e da Casa Verde. "É matéria de ciência", diz Porfírio, respeitando a instituição que, antes de vitorioso, jurara destruir. As duas revoltas, que se destinavam a derrubar a tirania do Alienista, só fizeram fortalecê-lo, permitindo que trancafiasse a Porfírio e outros cinquienta e tantos indivíduos que declarou mentecaptos, além do pobre Crispim Soares, punido por sua covardia. "O terror também é pai da loucura", declara o Alienista, ele que, sabemos pelo texto de Machado, instaurara o terror.

A partir deste ponto, instaladas em Itaguaí as forças do vice-rei, o poder do Alienista é total. "Tudo era loucura" - inclusive o apego de D. Evarista 
às sedas, veludos e rendas. Diagnosticada como portadora de "mania suntuária", também foi trancafiada. Assim, colocando os ditames da ciência acima dos laços de casamento e afeto que o ligavam a D. Evarista, o Alienista superouse como homem a quem só a ciência importava. "Ninguém mais tinha o direito de resistir-lhe - menos ainda o de atribuir-lhe intuitos alheios à ciência" (p. 280).

Novamente os dois discursos confluem para o mesmo ponto. O desastre afetivo e humano que é Simão Bacamarte reúne-se ao triunfante homem de ciência que é o Alienista. Ao trancafiar a própria esposa, impondo ao miúdo sentimento de amor os compromissos para com a ciência, o Alienista já se encontra além dos limites daquilo que é simplesmente humano. E terá sido este um dos limites entre razão e loucura que não lhe ocorreu investigar.

Recebido para publicação em agosto/1993

GOMES, Roberto. The Alienist: madness, power and science. Tempo Social; Rev. Sociol. USP, 5(1-2): 145160, 1993 (edited in nov. 1994).

ABSTRACT: This article analyzes Machado de Assis' short story The Alienist. Centered on the delusions of Simão Bacamarte, a physician and psychiatrist, in this fiction are reflected the impasses and intentions of the scientific conceptions of the nineteenth century, particularly of the Positivism which has profound links with the birth of the Humanities. On the one hand, the thirst for a scientifically sound explanation of its object, in this case Madness, and on the other the right he attributes himself of arbitrating on Madness and the Mad, and of acing upon these arbitrations with complete and total powers. Machado de Assis' work denounces the link between science and power, as well as the appropriation by men of science of the right each individual possesses of telling his or her own truth. This conducts the story to its final irony: there seems to be more madness in the pretension of establishing clear-cut limits between Reason and Madness than in losing oneself between these proposed limits.

\section{REFERÊNCIASBIBLIOGRÁFICAS}

Assis, Machado de. (1979) O Alienista. In: Obra Completa. Vol. II, Conto e Teatro. Organizada por Afrânio Coutinho, $4^{\mathrm{a}}$ edição, ilustrada. Rio de Janeiro, Editora Nova Aguilar, p. 253-288.

Foucault, Michel. (1978) História da loucura na Idade Clássica. Trad. de José Teixeira Coelho Netto. São Paulo, Editora Perspectiva. 
. (1979) Microfísica do poder. Organização e tradução de Roberto Machado. Rio de Janeiro, Edições Graal.

. (1987) As palavras e as coisas. Uma arqueologia das ciências humanas. Tradução Salma Tannus Muchail, $4^{\mathrm{a}}$ edição. São Paulo, Martins Fontes Editora. 